\title{
Благоевич М.
}

\section{ДЕСЕКУЛЯРИЗОВАННОЕ ОБЩЕСТВО КАК ПОКАЗАТЕЛЬ ВИТАЛЬНОСТИ РЕЛИГИИ}

доктор социологических наук, ведущий научный сотрудник, руководитель FOREL Института общественных наук. ул. Краљице Наталије, д. 45, Белград, Сербия. Электронный адреc: blagomil91@sbb.rs

\begin{abstract}
Аннотация. В своей работе автор делает попытку показать, что не подтвердились прогнозы отдельных теоретиков, философов и социологов теории секуляризации о неизбежном исчезновении или маргинализации религии в процессе модернизации общества. Религия выжила, а в некотором отношении предвестила свое возвращение в общество и значение не только для индивида, но и для коллективных представлений и действий. Детерминистические рамки поворота от секуляризации к десекуляризации общества складываются из сплетения нескольких важных изменений общества. С одной стороны, имеет место приобретение религиозной традицией политического значения, а с другой стороны, упомянутые традиции, предвещая свое возвращение, деприватизируют принятые, синкретические верования и поведение, что является существенными элементами процесса десекуляризации религиозной жизни. Многие социологи и специалисты по религиоведению в период указанных общественных событий с середины 70-х видят религию, которая, готовя свое возвращение, ставит под серьезное сомнение тезис секуляризма или же сужает его в культурно-географическом смысле, ограничивая Европой или даже только Северной, точнее Западной Европой, как ранее предложил это «правоверный» сторонник парадигмы секуляризма Питер Бергер, а затем и Дэвид Мартин.
\end{abstract}

Ключевые слова: теории секуляризации; маргинализация религии; процесс модернизации; десекуляризация; рынок религиозных взглядов.

\section{Blagojevic M. \\ DESECULARIZED SOCIETY AS AN INDICATOR OF THE VITALITY OF RELIGION}

Doctor of Social Sciences, Chief Researcher, the head of FOREL Institute of Social Research 45, Queen Nataliya, Belgrade, Serbia. E-mail: blagomi191@ @bb.rs

\begin{abstract}
The author aims to show that the forecasts of some theorists, philosophers and sociologists about the secularization and inevitable disappearance and marginalization of religion in the process of modernization of society, did not come true. Religion as a social institution has survived and has indicated its return to society and its importance not only for the individual but also for the collective consciousness and action. Deterministic frameworks of the processes of religious changes toward desecularization of society are the result of important changes in society itself: on the one hand the religious traditions acquire political significance and importance in the society, while on the other side they deprivatize faith and behavior of individuals, which can be considered as representing the crucial elements of the process of desecularization of society. These examples compelled the authors like David Martin and Peter Berger to review their theories about secularization of society during 1960s and 1970s, by presenting new ideas about desecularization of society or by limiting the theory of secularization to Western Europe countries only.
\end{abstract}

Keywords: theory of secularization; marginalization of religion; process of modernization; desecularization; market of religious ideas.

Как определить десекуляризацию

Проявление отдельных элементов десекуляризации общественной жизни мы встречаем еще с 70-х годов прошлого века. Однако, только в конце прошлого и в начале нового века робко ставится вопрос концептуализации теории десекуляризации и лишь немногие авторы рассматривают проблемы и неоднозначность религиозных изменений в направлении десекуляризации подобно авторам, 
которые в течение 50-70-х годов прошлого века занимались понятием и процессом секуляризации. Парадокс состоит возможно и в том, что в отдельных случаях речь идет об авторах, которые за минувшие время подорвали свои собственные теоретические исходные установки. Парадигматичным является пример Питера Бергера, бывшего некогда одним из серьезных сторонников теории секуляризации [1], который в конце прошлого века в своем, сейчас известном и часто цитируемом тексте [2; 3], пишет о процессе десекуляризации многих обществ и даже всего мира, и о том, что предположение, что мы сегодня живем в секуляризованном мире ошибочно. «Сегодняшний мир, если не считать некоторых исключений, ...безмерно религиозен, каким был и всегда, а в некоторых районах даже больше, чем ранее. Это значит, что вся литература, созданная историками и социологами, которые достаточно легко опубликовали «теорию секуляризации», по существу ошибочна» $[3, \text { с. } 12]^{1}$. А больше всего ошибочно предположение просветительства, что модернизация ведет непосредственно к снижению роли религии и религиозности, хотя это предположение может быть точным для некоторых обществ, например на Западе, и оттуда определенные географическо-цивилизационные сокращения парадигмы секуляризации, к которым прибегает Дэвид Мартин [4, с. 123-128; 5, с. 2324]. Ясно, тем не менее, что отношения между модерностью и религией непростые и неодносторонние ни в обществах Запада, не говоря уже о тех обществах, которые не принадлежат к данной группе обществ ${ }^{2}$. При всем

\footnotetext{
«Разрешите мне повторить то, что я уже сказал. Сегодняшний мир в массе религиозен и является чем угодно, но только не секуляризованным миром, предсказанным (с радостью или с опасениями) многими аналитиками современной эпохи» [3, с. 20]. «Не существует ни одной причины, чтобы думать, что в двадцать первом веке мир будет немного менее религиозен, чем сегодня» (стр. 23).

2 О классическом тезисе в социологии религии во второй половине прошлого века об отношениях между модернизацией и секуляризацией известный британский автор, Грейс Дейви (Davie) пишет: «Тезис о секуляризме возник в рамках Европы и для определенных фаз европейского религиозного развития существует убедительное соответствие между аргументами и фактами. По мере развития экономической и политической жизни в Европе религия теряла общественное значение, религиозные устремления были перенесены в сферу частной жизни. Мало-помалу аргументы взяли верх над фактами. Их «соответствие» стало аксиоматическим, теоретически необходимым в большей мере, чем было эмпирически оправдано - в такой мере, что европейская религиозная жизнь считалась прототипом глобальной религиозности: все, что Европа сделает сегодня, все остальные сделают завтра. Секуляризация была составной частью модернизации и с
}

этом особенно важны общественные группы и индивиды, которые не приспосабливаются к современному секуляризованному миру, а борются против секуляризации или секуляризма. При этом мы не принимаем во внимание тех индивидов и общественные группы, которые не проявляют активности в этом противостоянии, но не могут вынести состояние относительности общественных ценностей, индивидуализма, неопределенности и неуверенности в современном секуляризованном мире. Консервативные, ортодоксальные и традиционные религиозные организации и движения не только в христианстве, но и в других мировых религиях, - пишет Бергер, которые на международной религиозной сцене активны в отрицании или борьбе с эффектами секуляризации, повсюду в экспансии в отличие от тех движений и организаций, которые в течение многих десятилетий вложили много энергии в то, чтобы приспособиться к современному миру. Все это важно как раз потому, что современный процесс десекуляризации в первую очередь определяется и понимается в виде контрасекуляризации и должен обозначать общественный процесс, противоположный процессу секуляризации [6; 7]. Это, с другой стороны, говорит о сложности религиозной и глобальной общественной ситуации: во многих современных обществах сосуществуют секуляризационные и контрасекуляризационные тенденции, деятели и силы и их изучение как процессов, которые не взаимоисключают друг друга, и далее является важной задачей современной социологии религии.

Примеры витальности религии: в прошлом и в настоящем

Детерминистические рамки поворота от секуляризации к десекуляризации общества складываются из сплетения нескольких важных изменений общества, относительно которых у социологов в основном нет разногласий, которые парадигматично подтвердили изменение как положения самой религии и религиозных институтов в обществе, так и духовной атмосферы в культуре. С одной стороны, имеет место приобретение религиозной традицией политического значения, а с другой стороны, упомянутые традиции, предвещая свое возвращение, деприватизируют принятые, синкретические верования и поведение, что является существенными элементами процесса десекуляризации религиозной жизни. Речь идет о

модернизацией мира автоматически происходила его секуляризация» [8, с. 93]. 
событиях, которые показали, что религия не проиграла, т.е. что она опять восстановила потенциалы, чтобы вдохновить значительные коллективные усилие людей, направленные на изменения, которые касаются самой сути их политической и религиозной жизни. Даже в Европе, центре процесса секуляризации в начале 80-х годов религия и церковь начинают публично выступать с все более очевидными политическими притязаниями. И католическая, и протестантские церкви поднимают свою голос против ядерного вооружения, а также против загрязнения окружающей среды, подчеркивая таким образом не только свою современность, но и ангажированность, касающуюся ключевых вопросов и проблем современного мира. В это время, или несколько позже, и в коммунистических странах религия начинает играть все более заметную роль в обществе, прежде всего в Польше, а затем и на Балканах в ситуации военных конфликтов и распада югославской социалистической федерации. Занятые делами, которые в значительной мере превосходят заботу о душе, религиозные организации в упомянутых регионах приобретают ощутимый вес в обществе, который используется больше всего в политике, что является очевидным сдвигом по сравнению с предыдущим десятилетием при социалистическом строе.

Многие социологи и специалисты по религиоведению в период указанных общественных событий с середины 70-х видят религию, которая, готовя свое возвращение, ставит под серьезное сомнение тезис секуляризма или же сужает его в культурно-географическом смысле, ограничивая Европой или даже только Северной, точнее Западной Европой, как ранее предложил это «правоверный» сторонник парадигмы секуляризма Питер Бергер, а затем и Дэвид Мартин. Как мы уже отметили, Бергер кратко обосновывает отдельные важные тезисы парадигмы секуляризма, среди которых и тезис о неизбежном последствии модернизации - снижении значения религии как в смысле общественных институтов, так и в смысле индивидуального сознания. Этот тезис основан на ряде предпосылок, которые Юрген Хабермас систематизирует следующим образом: первая предпосылка касается научно-технического прогресса, который влияет на развитие антропоцентричного понимания развенчанного мира в ущерб теоцентричным и метафизическим картинам мира; второе, в процессе дифференциации общественных подсистем, церкви и религиозные общины теряют влияние на правоведение, политику, культуру, образование, науку - и ограничиваются предоставлением «милости Божьей» тем, кому она необходима, теряют прежнюю роль в обществе и третье, в индустриальном и постиндустриальном обществе возрастает экгзистенциальная безопасность людей и исчезает потребность людей прибегать к Богу или потусторонним силам, чтобы обуздать обстоятельства, на которые невозможно влиять [9].

Но эта теория никогда не была подтверждена эмпирически и споры вокруг нее в конце 70-х годов прошлого века, становясь яростными, ставили ее сторонников в неловкое положение, вынуждая корректировать теорию определенным культурно-географическим ограничением, так что она «была, также как сегодня, правильной для одной части мира, для Европы, нескольких обособленных территорий и немногочисленных европейски образованных интеллектуалов в разных странах мира. Остальное человечество является столь же глубоко религиозным, как и раньше, вероятно даже больше, чем это было в начале века» [5, с. 23-24]. Причины неспособности социологов объективно представить религиозную ситуацию в мире автор видит не только в идеологических убеждениях социологов, но и в их ограниченности: социологи плохо знают «остальной мира», поскольку действительно живут в секуляризованной среде, далекой от верований и религиозной практики.

Мартин признает энергичный ход секуляризации в Западной Европе в виде определенных обстоятельств, таких как конфликт церкви и просвещения, разрыв органического сообщества (урбанизация) и появление мегалополисов. Однако, даже в этих обстоятельствах отдельные национальные сообщества или субсообщества, которые выносили чужую и внешнюю власть (Польша, Ирландия, Страна Басков, Фландрия, Словакия, Хорватия и Бретань, затем миграционные мусульманские общины в современной Европе) находят свой источник и идентичность в исторической вере и их религиозность заметно более жизнеспособна, чем где-либо в другом месте. Констатируя, что Европа не является центром мира, и изучая религиозную ситуацию в Северной и Латинской Америке и на исламском Ближнем Востоке, а также в Северной Африке, Мартин показывает, что в тех областях динамика религии несколько отличается от европейского опыта и европейского образца религиозных перемен и приходит к идее о необходимости фундаментального сужения действия парадигмы 
секуляризма на Европу, где «социологическая модель секуляризации создана и, возможно, поэтому к ней и относится» [4, с. 123-128].

Любопытно при этом то, что индивидуализация, всеобщая рационализация общественной жизни и общественноэкономическое развитие, столь характерные для европейского опыта модернизации и секуляризации, не действительны для других территорий с теми же самыми характеристиками. В качестве лучшей иллюстрации этого чаще всего приводят Соединенные Штаты Америки. В протестантских странах Европы процесс секуляризации наиболее выражен по сравнению с другими конфессиональными областями Европы, чего никак нельзя сказать о протестантских США с весьма многочисленными и активными церквями и высоким уровнем религиозной веры. Здесь как будто не действует тезис о модернизации и секуляризации общества как ее последствия. Секуляристы находили ответ в определении специфики, точнее отличии Америки. Эти отличия заключались в нескольких важных аспектах истории Америки и развития культуры на этой территории: в Соединенных Штатах религиозные организации традиционно играют важную роль в социализации и интеграции людей в общество путем формирования групповой солидарности; там существовал плюрализм, характерный для культуры в целом, и в итоге религия в Америке исторически сопровождала модернизацию. Другие авторы толковали тезис о секуляризации и модернизации общества в контексте европейской эксклюзивности процесса секуляризации, где теория секуляризации хорошо объясняет общественные и религиозные изменения, являясь при этом не вполне эффективной для остального мира.

Тарнер выделяет несколько макро социальных факторов, которые могут помочь в объяснении актуальности религии в современном мире. В первую очередь он выделяет крах организованного коммунизма и упадок марксистско-ленинской идеологии в Европе, особенно в Польше, Украине и бывшей социалистической Югославии. Наиболее важной была связь между православной церковью и русским национализмом и патриотизмом с примерами периода II мировой войны и постсоветского периода. Но и в других коммунистических странах, от Вьетнама, Кубы до Камбоджи, возвращение к религии происходит изза разочарования людей в упомянутой идеологии.

Второй фактор касается глобализации и роста миграций в мире и расселения мигрантов в странах с развивающейся экономикой, где их до того времени не было, что привело к возникновению диаспорных общин, которые чаще всего складываются на религиозноэтнической основе. Примером этого являются турки исламского вероисповедания в Германии, китайские буддийских меньшинства по всему миру и т.д. «Сложная связь между религией и политикой идентичности устанавливается повсюду в мире - от индуизма в Индии до католицизма в Польше и синтоизма в Японии и таким образом религия становится частью внутренней структуры публичной сферы общества» [10, с. 31]. С другой стороны, такая ситуация порождает напряженность и конфликты, не существовавшие ранее. Любопытны данные, отражающие опыт Европы, и статистика. Так, по данным Европейского социологического исследования (The European Social Survey, ESS, Round 4, 2008-2009) в странах Европы абсолютное большинство верующих составляют представители христианских конфессий, так что религиозно-конфессиональная карта показывает, что Европа остается христианской. Но упомянутые современные миграционные процессы и социокультурные тенденции привели к ослаблению ранее однородного культурнорелигиозного европейского пространства. На этом пространстве можно наблюдать различные этнические и религиозные группы, которые относят себя к другим религиозным традициям, прежде всего к исламу. Например во Франции 8\% верующих исламского вероисповедания, в Бельгии $-6 \%$, в Швеции - 5\%, Швейцарии $-5 \%$, а в Великобритании - 4\% [11, с. 23]. Интересно, что доля мусульман больше как раз в тех европейских странах, в которых установленный уровень религиозности коренного населения особенно низок. Отсюда вытекает серьезная проблема при поиске возможностей для мирного сосуществования различных религиозных традиций, a также большой вызов для государства, которое должно регулировать взаимные отношения этих традиций, что, как пишет Тарнер, может заставить его отказаться от традиционно либерального подхода, предполагающего отказ государства от вмешательства в дела церкви. Например, в США и Сингапуре государство начинает регулировать ислам, чтобы включить в общество «умеренных мусульман».

В качестве третьего фактора присутствия и публичности религии в современном мире Тарнер приводит слом постколониального секулярного 
национализма на Ближнем Востоке и в Северной Африке и подъем духовной революции (Иран) и различных видов радикального ислама, имеющих свои корни, с одной стороны, в массовом протесте против банковского сектора и коррумпированных и авторитарных секулярных структур власти, а с другой стороны, в борьбе за защиту культурной и религиозной идентичности против либерального и секулярного влияния Запада.

На секуляризацию, указывает Тарнер, можно смотреть и другими глазами, а именно, в контексте современного превращения религии в товар на рынке религиозных идей и практик. Это новое в либеральном обществе, поскольку раньше на религию смотрели как на систему идей и практики, основанной на неизъяснимой природе религиозной коммуникации. Сейчас религия изъяснимое выражение, которое имеет свой сбыт на рынке и поэтому в полной мере совместима с современным миром.

\section{References}

1. Berger, Peter (1969) The Sacred Canopy, Elements of a Sociological Theory of Religion, New York.

2. Berger, Peter (1999) The Desecularization of the World: A Global Overview, The Desecularization of the World: Resurgent Religion and World Politics, Grand Rapids: Wiiliam B. Eerdmans Publishing Company.
3. Berger, Piter L. (2008) Desekularizacija sveta preporod religije i svetska politika, Meditteran Publishing, Novi Sad.

4. Martin, Dejvid (1994) „Pitanje sekularizacije: perspektiva i retrospektiva", u Povratak svetog? Niš, Gradina.

5. Berger, Piter (2001) „Sociologija: povlačenje poziva", u Đorđević, B. D. Sociologija forever, Niš, Punta.

6. Karpov, Vjaceslav (2010) „Desekularization: A Conceptual Framework", Jouranl of Chursh and State, Vol. 52, No. 2., P. 232-270.

7. Карпов, Вячеслав (2012) „Концептуальные основы теории десекуляризации", Государство, религия, церковь в России и за рубежсм, № 2., С. 114-164.

8. Dejvi, Grejs (2008) „Evopa: izuzetak koji dokazuje pravilo? ", u Piter L. Berger (priredio) Desekularizacija sveta - preporod religije $i$ svetska politika, Meditteran Publishing, Novi Sad.

9. Habermas, Jirgen (2008) „Dijalektika sekulaeizacije", Nova srpska politička misao, Beograd, 29. april 2008., URL: http://www.nspm.rs/granicemultikulturalizma/dijalektika-sekularizacije.html, posećeno 23. decembra 2009.

10.Тернер, Брайан (2012) „Религия в постсекуларном обществе", Государство, религия, иерковь в России и за рубежсом, № 2., С. 21-51.

11. Kofanova Elena; Mčedlova Marina (2012) „Religioznost građana Rusije i Evorpe”, Filozofija $i$ društvo, br. 1, str. 21-39. 